\title{
МЕСТО И УЛОГА ЕКСПЕРИМЕНТАЛНЕ И ИСКУСТВЕНЕ АРХЕОЛОГИЈЕ У ИНТЕРПРЕТАЦИЈИ ПРОШЛОСТИ
}

\author{
Ана Ђуричић \\ Лабораторија за биоархеологију, Одељење за археологију, \\ Филозофски факултет, Универзитет у Београду \\ Видан Димић \\ Археолошки институт, Београд \\ e-mail: ana.djuricic@f.bg.ac.rs $\mid$ Прегледни рад \\ Примљено: 1. 8. 2020. УДК: 001.92:902.3 \\ Прихваћено: 4. 9. 2020. 37.018.58:902/904
}

\begin{abstract}
Апстракт: Експериментална археологија је као поддисциплина археологије дефинисана шездесетих година 20. века, међутим, юени зачеци се могу видети још у 19. веку. Развој експерименталне археологије одсликава и теоријско-методолошке промене кроз које је пролазила целокупна археологија. Експериментална археологија је прошла кроз бројне трансформације - од појединачних експеримената у 19. веку и првој половини 20. века, преко дефинисања теоријско-методолошког оквира, све до данашњих дана. Будући да се најпотпунији подаци могу добити приликом спровођења комплексних експеримената, у којима учествује велики број стручњака из различитих области археологије, у другој половини 20. формирају се истражсивачки центти експерименталне археологије. У оваквим иентрима, експериментални археолози праве читава насеља из различитих периода прошлости. Атрактивност ових насеља и могућност практичног преноса знаюа на ширу јавност отвара ова насеља за посетиоче. Ствара се нови концепт музеја - археолошки музеј на отвореном, чији број расте из године у годину. Интересовање за откривање живота у прошлости расте, те поред музеја на отвореном, јављају се и бројне емисије, а у последюих неоколико година, и специјализовани јутјуб канали који се баве традиционалним занатима. На тај начин, из експерименталне археологије настаје искуствена археологија, чији је фокус управо у преносу знања преко личних доживљаја, како археолога, тако и шире јавности. Циљ овог рада је да се прикаже развој експерименталне и искуствене археологије, како у свету, тако и у Србији.
\end{abstract}

Кључне речи: експериментална археологија, искуствена археологија, теоријска археологија, методологија

\section{Увод}

Експериментална археологија је, попут других друштвених и природних наука, током 20. века доживела низ промена, које су дефинисале њен садашњи облик. Иако су у почетку поједини археолози критиковали 
експерименталну археологију као недовољно научну област археологиje, услед непостојања дефинисаног методолошког приступа, средином 20. века, уз велико залагање малог броја истраживача, она успева да постигне широку научну афирмацију (Ascher 1961; Coles 1966; 1973; 1979). Како су се теоријски приступи у археологији мењали, тако се мењао и поглед на улогу и функцију археолошког експеримента.

Са утврђивањем теоријско-методолошких оквира експерименталне архологије, јавља се потреба за експериментима у којима учествује велики број стручњака. Њихово спровођење изискивало је формирање издвојених истраживачких центара експерименталне археологије. У оквиру ових центара настају целокупна насеља и отварају се за посете шире јавности. Из истраживачих центара експерименталне археологије настају археолошки музеји на отвореном, у којима се нужно не спроводе експерименти, већ се реконструише начин живота у прошлости. С појавом археолошких музеја на отвореном и развојем савремених технологија, јавља се још једна област археологије, која се ослања на експерименталну археологију - искуствена археологија.

Циљ овог рада је да прикаже развој експерименталне археологије од њених почетака као још недефинисане поддисциплине у оквиру археологиje, до данашњих дана, како у свету, тако и у Србији. Значајан корак у развоју експерименталне археологије чини и дефинисање искуствене археологије. Будући да често долази до забуне приликом употребе ова два термина, један од циљева рада је и да се прикаже разлика између експерименталне (experimental) и искуствене (experiential) археологије.

\section{Развој експерименталне археологије}

Још током 19. века, археолози су почели да производе и користе реплике археолошких артефаката како би покушали да одреде њихову функцију. Међутим, овакви експерименти су представљали изоловане случајеве и нису били део неког ширег археолошког истраживања (Carrell 1992, 4). Неке од првих експеримената спровели су: С. Нилсон (Nilsson 1868) у Данској, Џ. Еванс (Evans 1860; 1881) у Енглеској, Џ. Макгвајер (McGuire 1891; $1892 ; 1893 ; 1894)$ и Ф. Х. Кушинг (Cushing 1894) у Сједињеним Америчким Државама (Ascher 1961, 794). Њихови експерименти базирали су се махом на испитивању техника израде и употреби различтих врста предмета (од окресаног и глачаног камена, керамике и метала), док су структуре, попут пећи за топљење бакра, биле у фокусу тек малог броја истраживача (Cushing 1894: 94-95). 
Ови појединачни примери раних експеримената илуструју потребу археолога за разумевањем артефаката које проналазе, али непостојање установљеног теоријско-методолошког оквира и њихове шире научне утемељености класификује их као један корак у развоју ове поддисциплине, а не као производе експерименталне археологије.

У првим деценијама 20. века експерименти у археологији постају све чешћи. У фокусу истраживача још увек су, махом, појединачни предмети, међутим, осим израда реплика, археолози почињу да се баве и испитивањима трагова употребе, компаративним анализама итд. Један од раних експеримената спровео је Сире (Siret 1925), са циљем да идентификује кости коришћене за ретуширање мустеријенских кремених алатки. Посебно се издвајају експерименти С. Курвена (Curwen E. Cecil) (Curwen 1930; и накнадно поновљени експеримент 1935), који се бавио траговима употребе на кременим сечивима. Курвен је спровео експеримент израде и употребе сечива натуфијенске композитне алатке (интерпретиране као срп), пронађене у једној од неколико пећина на планини Кармел (Mount Carmel) у Израелу. У циљу утврђивања трагова употребе, упоређивани су трагови видљиви на оригиналним сечивима са оним на експерименталним сечивима. Реплике су тестиране сечењем различитих материјала (слама, дрво и кост). Тип сјаја који се јавио на репликама након сечења сламе у највећој мери је одговарао сјају видљивом на оригиналним сечивима српа (Ascher 1961, 794). Резултати Курвеновог експеримента допринели су успостављању једне од главних категорија за дефинисање сечива коришћених у пољопривреди (срп) - силикатног сјаја - и постали су један од првих доказа о раној земљорадњи на Блиском истоку (Curwen 1935). Треба истаћи и експерименте скандинавских истраживача: Ј. Иверсена (Iversen 1956), С. Јоргенсена (Jorgensen) и А. Стинсберга (Steensberg 1957), усмерених ка испитивању каменог оруђа са сечицом и реконструкцији пољопривредних активности у неолиту Селанда. Њихов најпознатији експеримент потврдио је могућност практиковања тзв. slash-andburn земљорадње, којом се плодно обрадиво земљиште ствара преко сече и паљења шума и поља (Iversen 1956; Steensberg 1957). Технологијом израде и употребом праисторијских оруђа од кости, рога и камена бавио се и руски археолог С. Семјонов (Semenov 1964). У својим анализама, Семјонов комбинује етноархеолошка истраживања, археолошке имитативне експерименте и анализе трагова употребе (трасеолошке анализе), чиме поставља стандарде у проучавању поменутих категорија археолошког материјала.

Значај наведених експеримената не огледа се само у њиховим револуционарним резултатима већ и у другачијој перцепцији и поставци експе- 
римента. Они су најава новог позитивистичког приступа у експерименталној архологији и дефинисања ове поддисциплине.

У другој половини 20. века, заједно са значајним променама у археологији и успостављањем позитивитичког приступа (Џонсон 2008 са референцама), експериментална археологија почиње да се формира као поддисциплина, добијајући свој теоријско-методолошки оквир (Coles 1979; Mathieu 2002; Cunningham et al. 2008). Експеримент у археологији постаје средство за тестирање хипотеза или истраживачких питања. У том периоду настају и бројни радови још увек релевантних експерименталних археолога: Ашера, Колса, Рејнолдса, Сарајдра и Шимаде, Стоуна и Планела, Метјуа, Тексијеа, Пелеграна и других (Ascher 1961; Coles 1966; 1973; 1979; Saraydar and Shimada 1973; Reynolds 1976; 1979; 1980; 1985; 1994; 1999a; Stone and Planel 1999; Mathieu and Meyer 1997; Mathieu 2002; Texier 1984a; 1984b; Pelegrin 1982; 1984a; 1984b; 1984c; 1988). Појединачни експерименти постају велики пројекти. Оснивају се и истраживачки центри у Данској - Експериментални центар Лејрe (Experimental Centre at Lejre), и Великој Британији - Древна фарма у Батсеру (Butser Ancient Farm), у којима се спроводе експерименти израде, употребе и пропадања предмета и структура. Овакви центри представљају идеалну локацију за проучавање тафономских процеса. У њима се деценијама граде куће и израђују предмети, те је могуће пратити процесе који настају након напуштања стамбених објеката и одбацивања предмета (Niels 2006; Holtorf 2014). Будући да је препознат потенцијал који могу имати у промоцији археологије и реконструкцији живота у прошлости, овакви центри отварају се и за посетиоце. Тиме се у њима спроводи и едукација не само шире јавности већ и будућих археолога (Reynolds 1999b). Оваква пракса постаје широко распрострањена и данас постоји велики број сличних центара у свету (примери на: http:/openarchaeology.info/ category/archaeological-open-air-museum).

Иако данас широко прихваћена, експериментална археологија је трпела критике. Један од критичара експерименталне археологије, Р. Трингам, навела је два главна разлога због којих је ова поддисциплина са правом, по њеном мишљењу, била занемарена у археолошким истраживањима. Прву мањкавост експерименталне археологије види у недостатку јаке теоријске базе која резултира немогућношћу да се генерално примени у тестирању археолошких хипотеза. Други је недостатак озбиљности и мањак пажње усмерен ка научним (science) експерименталним процедурама када је реч о припреми, извођењу и документовању експеримента и анализа (Tringham 1978, 171). С појавом постпроцесне археологије, долази до критике пози- 
тивистичког приступа у археологији, а самим тим и археолошког експеримента утемељеног у стриктном хипотетичко-дедуктивном приступу (Beck 2011). За разлику од Р. Трингам, поједини критичари мисле да су археолошки експерименти превише научно оријентисани. Сматрају да археолошки експеримент, поред тога што тежи егзактности, треба да садржи, истражи и покуша да разуме и субјективне - људске елементе (мотиве, осећаје, емоције, понашање). Сходно томе, користећи се искључиво научним приступом (science), истраживачи лако могу да упадну у замку и пропусте „хуманистички" - социјални аспект прошлости (Cunningham et al 2008: vi). Дискусије o циљевима и методологији ексеприменталне археологије још увек трају, а међу заговорницима хуманистичке експерименталне археологије махом су скандинавски археолози: М. Расмусен (Rasmussen 2001; 2007), А. Бек (Beck 2011), Б. Петерсон и Л. Е. Нармо (Petersson and Narmo 2011).

Археолошки експеримент је од почетка присутан у археологији, мада је с временом мењао форму, фокус, циљеве и методологију. Веома рано је уочено да су експерименти добар начин презентације археологије, културне баштине и прошлости, што је свакако допринело популарности и очувању праксе извођења експеримената. Данас постоји велики број археопаркова и музеја на отвореном у којима се спроводе археолошки експерименти. На тај начин експеримент је из чисто научне сфере прешао у сферу туризма, едукације и забаве. Телевизијске куће су почеле да снимају емисије утемељене на експерименталној археологији. Једна од првих емисија је и била Живот у прошлости (Living in the past), снимљена 1978. године у продукцији Би-Би-Си-ја. Данас постоје бројне емисије у којима се на забаван начин приказују разни аспекти живота у прошлости.

\section{Експериментална археологија - теоријско-методолошки оквир}

Експериментална археологија је као засебна поддисциплина дефинисана шездесетих година прошлог века, са циљем да објасни технолошки аспект људске прошлости - израду и употребу различитих предмета и структура. Експериментална археологија је одговор школе процесне археологије на тежњу ка емпиријском приступу изучавања прошлости, уз ослањање на провере, хипотезе, процесе, законе, системе и објашњења. Поред реконструисања процеса израде и употребе предмета, ова поддисциплина се бави и праћењем стварања археолошког записа преко тафономских или друштвених процеса напуштања или уништавања предмета или конструкција. Етноархеологија често иде руку подруку са експерименталном археологијом и има циљ да премости јаз између савременог човека који изводи 
експеримент и статичног археолошког записа, описујући процесе производње и употребе предмета код неиндустријских заједница (Грин 2003, 330).

За дефинисање експерименталне археологије најзаслужнији су били археолози процесне школе археологије, који су предложили методологију спровођења експеримената (Asher 1961; Coles 1973; Reynolds 1998;1999a). Њихов приступ је још увек основа експерименталне археологије и темељи се на хипотетичко-дедуктивном методу. Целокпупан процес заснивао се на формирању хипотезе или сета истраживачких питања, који би били тестирани преко археолошког експеримента. На основу резултата експеримента, била би утврђена валидност хипотезе и/или понуђени одговори на постављена питања. Уколико би се утврдило да хипотеза није одржива, она би била одбачена. Првобитна хипотеза би била модификована на основу нових сазнања, а њена верификација би се истоветно спроводила. С друге стране, уколико би се утврдило да је хипотеза одржива и да је њена провера могућа уз понављање експеримента, сматрала би се валидном. Термин „валидна” не значи да је она апсолутно истинита, већ да је поткрепљена сетом података и разултата произашлих из експерименталне провере (Outram 2008, 1). Схватајући методолошке проблеме са којима се сусретала експериментална археологија, Колс даје осам смерница за спровођење експерименталних истраживања (Coles 1973, 15-18):

1. Коришћење материјала доступних заједници која је тема научног истраживања.

2. Служење техникама израде предмета и структура чије је практиковање потврђено или претпостављено код заједница које су тема научног истраживања.

3. Коришћење тековина савременог друштва са опрезом. Савремени алат не би требало користити приликом спровођења експеримента, али је пожељно користити анализе приликом одређивања материјала и савремену технологију за документовање експеримента (фото-апарат, камеру, рачунар, пирометар - прим. аут.).

4. Прављење детаљног плана извођења експеримента, пре почетка његовог спровођења.

5. Адекватно спровођење и документовање експеримента, како би се могао накандно поновити.

6. Успешност експеримента се не одликује само у изради предмета или структуре на један претпоствљени начин већ треба испробати више потенцијалних техника.

7. Успешан експеримент не представља апсулутну истину, већ једно од могућих решења. 
8. Оцењивање поузданости експеримента - од истраживачког питања, преко начина спровођења и документовања, све до блежења грешака до којих је дошло током експеримента.

Експерименти у археологији се могу поделити на две основне врсте - имитативне (израда копија предмета) и функционалне (употреба копија) (Coles 1966). Како би резултат експеримента био прецизнији, битно је анализирати материјале од којих су оригинални предмети прављени и користити исте материјале. У оба случаја потребно је направити копије предмета користећи оригиналне материјале (дрво, камен, кост, глину или метал), јер су једино такви експерименти валидни. Под имитацијом се не подразумева само да предмет личи на оригинал већ да се прави што приближније оригиналном техником. Израђујући реплике, археолози стичу увид у процес производње предмета у прошлости, док тестирање њихове употребе и праћење трагова насталих на њима може допринети правилној класификацији предмета (Coles 1966, 1; Carrell 1992, 5; Schiffer 2013).

Приликом израде реплике, најидеалније је употребити технике за које се претпоставља да су коришћене у периоду из којег оригинални предмет датира. За потребе израде брзих копија, могуће је прескочити одређене кораке, међутим, то утиче на распон добијених употребљивих података. Наиме, уколико правимо праисторијску кућу, и потребни су нам дрвени елементи за њену конструкцију, идеално би било користити копију камене секире. Ипак, често се посеже за комбиновањем техника (једно дебло исечено копијом камене секире, а остатак савременим алатом), или се пак користи искључиво савремени алат. На тај начин нам измиче податак о времену потребном за израду једног дрвеног стуба, али и подаци о потешкоћама на које је могуће наићи приликом њихове израде (Coles 1966, 2-3). Такође, за поједине категорије предмета, уколико се праве савременим алатом, немогуће је утврдити трагове који на предмету остају приликом његове израде. Приликом спровођења експеримената, за добијање најпотпунијих резултата неопходно је знати податке о техникама израде предмета у периоду који је у фокусу истраживања, економији заједнице и њеном природном окружењу. Такви подаци су кључни приликом одабира сировина, техника које ће бити коришћене, али и одређивања функције предмета, која може бити ограничена економским потребама дате заједнице (Carrell 1992, 5).

Рејнолдс истиче значај провере археолошког експеримента у будућности. Процес експерименталног истраживања види као циклични систем (Reynolds 1999a). Процес почиње истраживањем/испитивањем археолошких података, што доводи до формирања хипотезе и сета истраживачких 
питања. Њихово тестирање се обавља путем експеримента, из којег произилази сет резултата. Добијени резултати се упоређују са сетом примарних археолошкх података. На тај начин долази до потврде или одбацивања почетне хипотезе (Reynolds 1998; 1999a).

Археолошки експеримент пружа широк опсег података и резултата везаних за технологију израде и начин употребе археолошких објеката, односно предмета које каткад нисмо у стању да у потпуности разумемо из данашње перспективе. Колс наводи да је један од основних циљева експерименталне археологије репродукција некадашњих појава (Coles 1979, 1). Слично размишљање може се препознати и код Метјуа и Мејера, који истичу да је археолошки експеримент осмишљен тако да реконструише феномене из прошлости (Mathieu and Meyer 2002, 76). Рејнолдс се противи употреби термина „реконструкција” и упозорава да са његовом употребом треба бити обазрив. Истиче да је могуће реконструисати само оне елементе из прошлости за које постоје сви подаци, док би у супротном (пример праисторијских кућа) такве „реконструкције” биле плод маште и уметничке експресије (Reynolds 1994, 3).

Велики проблем у експерименталној археологији представља субјективност истраживача. Истраживач долази из другачијег културног окружења и живи другачијим начином живота. Он никада не може имати менталитет припадника заједница у прошлости и у потпуности разумети све аспекте њиховог духовног живота. Зато истраживач треба да тежи ка неутралисању личног утицаја, док фокус треба да буде на различитим природним факторима (Coles 1966, 3).

Свако ко се бави експерименталном археологијом мора бити свестан ограничења експеримента и не треба пренаглашавати његов значај. Циљ експеримента је да допуни знања о одређеном проблему, тако да има смисла једино у корелацији са осталим сегментима археолошких истраживања. На основу материјала и изгледа локалитета, стварају се хипотезе о употреби предмета и начину живота на локалитету, а циљ експеримента је да те хипотезе тестира. За разлику од експеримената у природним наукама, у којима су они директна потврда хипотезе, у археологији су они само показатељ једне од могућности. Дакле, археолошки експеримент нам пружа увид у један од могућих начина израде и употребе предмета, а не једини начин на који су људи у прошлости могли обављати дате активности (Coles 1966, 5; Coles 1973, 15).

Археологија се бави прошлим догађајима. Они су заувек нестали и њима истраживач никада неће моћи да присуствује. Експерименти крећу од претпоставке истраживача да је одређени предмет направљен и коришћен 
на одређени начин. Истраживач жели да потврди или оповргне ту хипотезу (Outram 2008, 2). Међутим, археолошки експерименти некад могу доказати да поједини предмети вероватно нису били коришћени у претпостављене сврхе. Пример за ово је могуће наћи у контекстима из бронзаног доба, у којима се јавља врста предмета од бронзаног лима, интерпретирана као штит. Његовом експерименталном израдом и употребом показано је да није функицоналан као дефанзивно оружје. Тачна намена предмета није утврђена, међутим, почетна хипотеза о дефанзивном оружју је са сигурношћу одбачена (Coles 1966, 6). Дакле, археолошки експеримент мора одговорити на специфична истраживачка питања. Треба да има јасно истакнуте циљеве или хипотезе, као и јасно назначене употребљене материјале и методологију, како би могао бити поновљен.

Циљеви истраживања експерименталне археологије обухватају три велике групе које се тичу питања спремања и конзумације хране, изградње и пропадања грађевина и структура и израде те одеређивања функције предмета (Coles 1966, 6-7). Археолошки експерименти се могу спроводити у контролисаним условима (лабораторији) или на терену. Контролисане лабораторијске експерименте одликује могућност понављања експеримената у високо контролисаним условима са веома малим бројем варијабли. Код експеримената на терену тешко је контролисати варијабле и фокус није на њиховој контроли, већ је њихов циљ да се реплицирају што приближније ситуације из прошлости, услед чега их је и теже поновити (Marsh and Ferguson $2010,4)$. Сматра се да успешна реплика треба да задовољи три критеријума. Прво, релевантни атрибути реплицираног предмета морају бити суштински идентични као код оригиналних примерака. Друго, отпаци или нуспроизводи израде морају да одговарају онима из археолошког записа. Треће, трагови употребе на предметима морају да одговарају траговима на археолошком материјалу. Прва два критеријума се често сматрају одлучујућим (Schiffer $2013,44)$. Међутим, увек треба имати на уму да резултати спроведених експеримената не дају коначне одговоре на постављена питања, нити увид у апсолутну истину, већ приказују неке од могућих начина израде и употребе предмета. Зато експериментална археологија не нуди магичну формулу за разумевање друштава у прошлости, већ сет опција и могућности, које је неопходно упоредити са осталим археолошким подацима.

\section{Експериментална археологија у Србији}

Експериментална археологија на нашим просторима нажалост није развијена као у другим деловима Европе и до сада у Србији није успостављен неки већи, дуготрајни експериментални пројекат. Сви археолошки ек- 
сперименти произашли су из личних иницијатива неколико истраживача и скоро сви су окончани након њиховог примарног спровођења.

Почетак екперименталне археологије код нас може се сместити у крај седамдесетих година 20. века, експериментом који су спровели С. Банкоф (S. Bankoff) и Ф. Винтер (F. Winter), у сарадњи са тимом археолога из Народног музеја у Београду. Током рекогносцирања терена у долини реке Мораве 1977. године, тим је наишао на напуштен омањи објекат грађен у техници плетера и лепа, у којем су видели идеалну прилику за испитивање процеса горења стамбених структура и њихових остатака. Након откупа, објекат је запаљен и читав процес је документован (Bankoff and Winter 1979). Оваквим експерименталним истраживањем они су тежили да боље разумеју процесе горења кућа и формирања лепа у винчанској култури. Сличном проблематиком неколико година касније бавила се и М. Стевановић. Њено истраживање се базирало на испитивању различитих врста материјала од којих су грађени стамбени објекти у касном неолиту централног Балкана, њихове реакције на излагање јакој ватри, анализи њихових остатака након горења и компарацији са оригиналним остацима лепа са винчанских локалитета (Stevanović 1985).

Након ових првих примера и покушаја успостављања експерименталне археологије у Србији, наступила је пауза дуга скоро две деценије. Године 2001. на локалитету Винча - Бело брдо одржана ја радионица израде керамичких посуда (Kapuran 2007). Године 2011, Ј. Вуковић спровела је експерименте израде и печења каснонеолитских керамичких посуда (Vuković 2011; 2018). Након тога, долази до већег интересовања за експерименталну археологију. Тако коауторка овог чланка, А. Ђуричић, у оквиру своје мастер тезе, 2012. године, на локалитету Винча - Бело брдо, спроводи експеримент израде и употребе каснонеолитске пећи са истоименог локалитета (слика 1) (Đuričić 2012; 2014a; 2018).

Године 2013, у сарадњи Народног музеја и Пољопривредног факултета у Београду, спроведен је археолошки експеримент израде неолитских композитних српова и њихове употребе у жетви. Експеримент је подразумевао и трасеолошке анализе и испитивање образаца стварања силикатног сјаја на сечивима. Руководилац експеримента била је В. Богосављевић Петровић из Народног музеја у Београду, док је у тиму, задуженом за извођење експеримента, био и коаутор овог рада, В. Димић. Жетва реконструисаним пољопривредним алаткама поновљена је и наредне 2014. године (Bogosavljević Petrović i dr. 2017) (слика 2). Годнине 2013. Народни музеј, у сарадњи са Завичајним музејом у Књажевцу и Институтом Сервантес, 


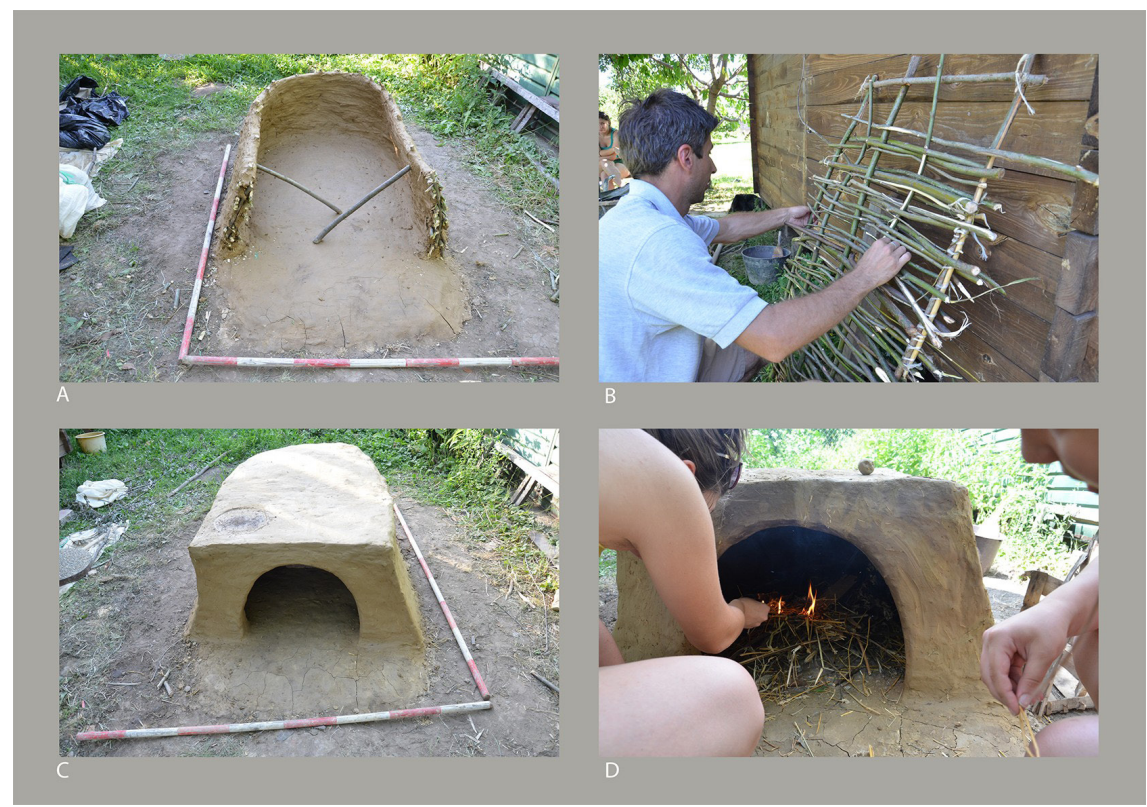

Сл. 1. Експеримент израде и употребе каснонеолитске пећи

(Đuričić 2014a, 266, Fig. 5)

Fig. 1. Experimental construction and use of a Late Neolithic oven (Đuričić 2014a, 266, Fig. 5)

спровео је пројекат израде реплике римске грнчарске пећи у селу Равна код Књажевца. Руководилац пројекта ове српско-шпанске сарадње била је Б. Ђорђевић из Нардоног музеја, а екипу су чинили стручњаци из Шпаније и коауторка овог рада, А. Ђуричић (Padilla Fernandez et al. 2014). Исте године, истраживачки тим пројекта Виминацијум реконструише погребни обичај спаљивања покојника код Римљана (Tapavički - Ilić and Mrđić 2015). Године 2014, М. Радивојевић са тимом спроводи експерименте топљења малахита, сакупљног на локалитетима Рудна Глава и Ждрело (Radivojević 2014).

Године 2014. спроведен је и пројекат Израда реплика фигурина са локалитета Благотин у оквиру Народног универзитета Трстеник, којим је руководила А. Ђуричић. У оквиру пројекта, покушана је израда и печење реплика фигурина, а резултати су приказани у оквиру изложбе Ожсивљавање прошлости: експериментално реконструисағе „Богиња са Благотина” у Музејској збирци Народног универзитета Трстеник (Đuričić 2014b). У оквиру израде докторске дисертације, А. Ђуричић је спровела низ експеримента израде и употребе ранонеолитских и каснонеолитских пећи и огњишта, у периоду од 2014. до 2018. године (Đuričić 2019). 

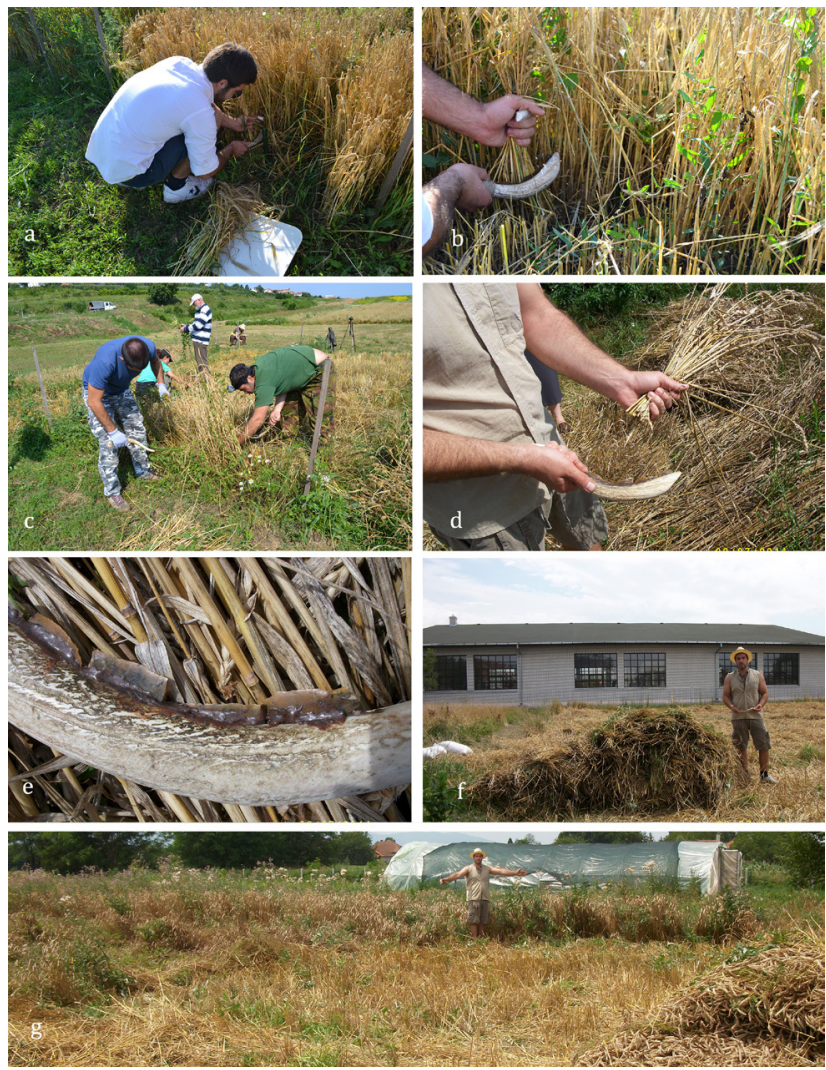

Сл. 2. Експериментална употреба српова, детаљи експеримента (Bogosavljević Petrović i dr. 2017, 49, Sl. 13)

Fig. 2. Experimental use of sickles, details of the experiment (Bogosavljević Petrović i dr. 2017, 49, Sl. 13)

Године 2017, коаутор овог чланка В. Димић спровео је експеримент на локалитету Прљуша - Мали Штурац, на планини Рудник. Експеримент се базирао на реконструкцији начина израде и употребе три основна типа рударских камених батова пронађених на поменутом локалитету (Dimić 2019) (слика 3). Исти истраживач је у оквиру своје докторске дисертације спровео дужи низ експеримената који су укључивали реконструкцију комплетног оперативног ланца израде и употребе неолитског глачаног каменог оруђа са сечицом, почевши од експлоатације сировине, израде оруђа, његове употребе, оштећења, поправке/оштрења до фрагментације (Dimić 2020). Ови експерименти пропраћени су сукцесивним трасеолошким анализама, чиме је формирана и референтна колекција трагова употребе глачаног каменог оруђа са сечицом у различитим дрводељским активностима. 

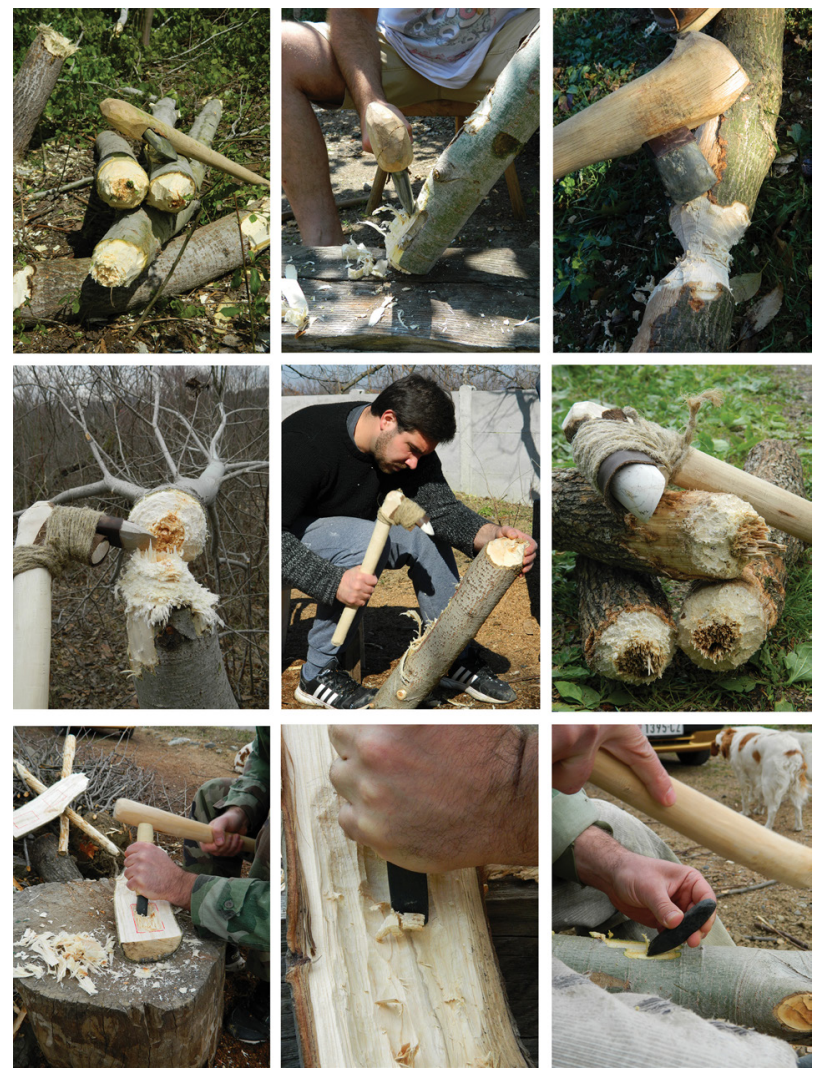

Сл. 3. Експериментална употреба глачаних камених секира, тесли и длета; детаљи из експеримента (фотографија: В. Димић)

Fig. 3. Experimental use of polished stone axes, adzes and chisels; details of the experiment (photo by V. Dimić)

Године 2020, А. Ђуричић и С. Живановић, у оквиру Археолошког музеја на отвореном СТАПАРК ${ }^{1}$ у Стапарима код Ужица, спровели су експерименте израде каснонеолитске пећи, одељка за складиштење и сточића од блатног малтера (слика 4). Експерименти употребе поменутих структура нису спроведени до тренутка писања овог чланка, али су планирани у будућности. У оквиру истог пројекта В. Димић је израдио више од две стотине предмета од кости, рога, камена, дрвета и керамике. Израда реплика ових предмета не представља пример експерименталне, већ искуствене археологије, о којој ће бити речи у наредном поглављу. Поменуте реплике израђене су махом помоћу савременог алата са циљем да прикажу претпостављени изглед алатки које су могле чинити инвентар неолитских кућа.

\footnotetext{
${ }^{1}$ Пројекат: „New life of Neolithic heritage in recognized natural areas of great importance - NeoLIFE”.
} 


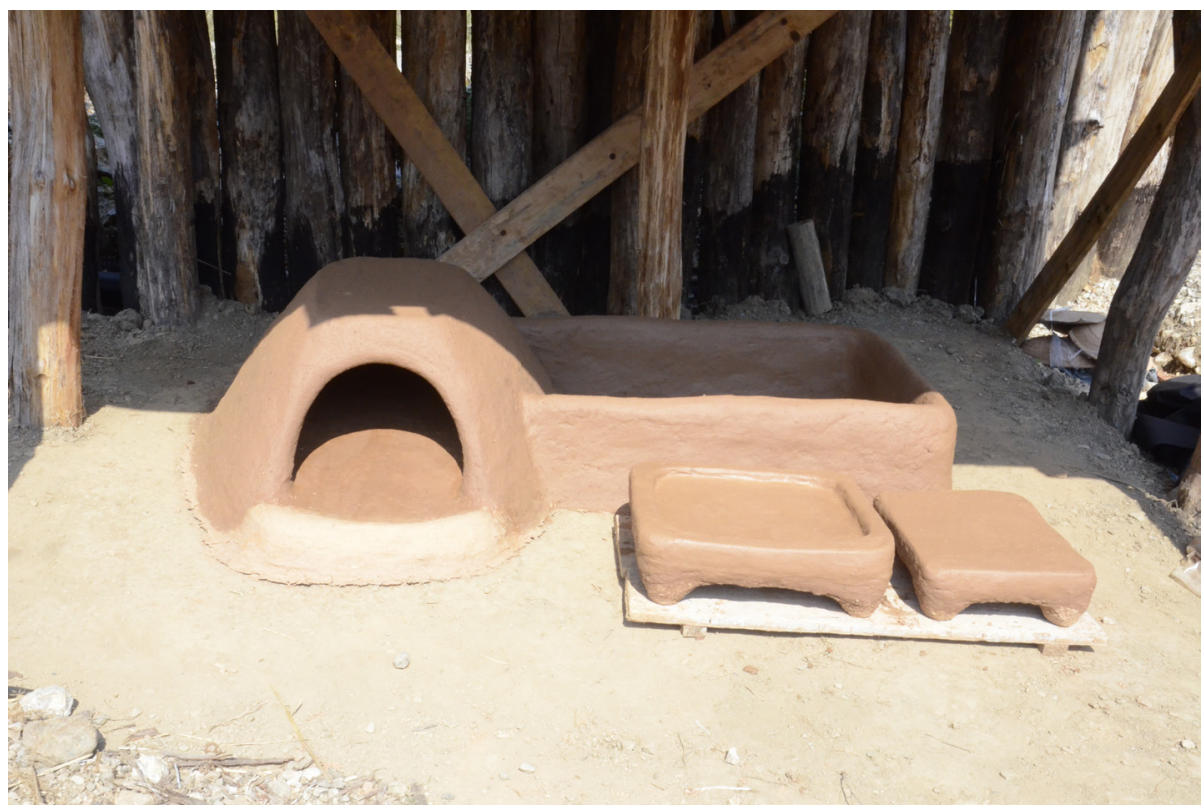

Сл. 4. Експериментална израда каснонеолитске пећи, одељка за складиштење и сточића (фотографија А. Ђуричић)

Fig. 4. Experimental construction of a Late Neolithic oven, storage compartment and small table (photo by A. Đuričić)

Последњих година значај експерименталне археологије препознат је и у нашој земљи. Демонстрација и истраживање праисторијских технологија израде и украшавања бронзанодопске керамике спроведена је кроз међународни пројекат „CRAFTER”, ${ }^{2}$ у коме су учествовали истраживачи из Немачке, Мађарске, Србије и Шпаније. У оквиру Српског археолошког друштва оформљена је и редовна секција за археометрију, археотехнологију, геоархеологију и експерименталну археологију, чији су организатори Д. Антоновић, С. Витезовић и К. Шарић.

Ова нагла експанзија експеримената у последњих десетак година свакако је веома охрабрујућа. Иако српска експериментална археологија касни за остатком Европе, с обзиром на повећано интересовање археолога, можемо очекивати још већи број пројеката и стручњака у будућности.

\section{Експериментална археологија и искуствена археологија}

Савремени начин живота, који често подразумева живот у градовима или гравитирање становништва ка урбаним центрима, развој технологије,

\footnotetext{
${ }^{2}$ Пун назив пројекта „Crafting Europe in the Bronze Age and Today”.
} 
индустрије и масовне куповине готових производа, током 20. века, одвојили су људе од бројних практичних знања која су поседовали или са којима су се свакодневно сусретали у прошлости. Данас купујемо прехрамбене намирнице на пијаци или у продавници, често конзумирамо већ припремљене оброке, одећа коју носимо углавном је масовно произведена у фабрикама, што је случај и са свим осталим предметима које имамо у становима и кућама саграђеним од савремених материјала, савременим алатом. Тек покоји украс у нашим домовима производ је рада занатлија или уметника, а не резултат масовне индустријске производње. Самим тим, како људи који изучавају прошлост, тако и људи који се за њу интересују, све слабије познају начин функционисања традиционалних заната и начина живота пре савремених тековина. С друге стране, постоји и повећано интересовање јавности за откривање живота у прошлости, што је делимично вероватно и последица извесне мистерије коју са собом доноси прошлост, али и свеопшта временска, а пре свега културолошка дистанца између савременог сложеног високотехнолошког друштва и наизглед једноставног живота пре појаве савремене технологије. Као резултат, јавља се све већи број комерцијалних емисија и документараца, поготово на специјализованим телевизијским или јутјуб каналима, који илуструју различите сегменте живота из прошлости, посвећене како интригантним темема и личностима, тако и људској свакодневици.

Захваљујући управо овом интересовању јавности за откривање начина на који су прављени и коришћени предмети и структуре у прошлости, како се живело у кућама од природних материјала без струје и текуће воде, све више се јављају музеји на отвореном. У овим музејима реконструишу се читава насеља из одређеног периода, израђују се бројне реплике предмета, а водичи, занатлије или демонстратори објашњавају посетиоцима како се предмети производе и користе. У појединим парковима на отвореном организоване су радионице у којима се посетиоци могу сами опробати у изради разних предмета уз инструкције демонстратора. Одређени музеји на отвореном нуде и вишедневни боравак, током којег посетиоци спавају у репликама кућа и живе у складу са периодом којем је посвећен дати музеј (Jakobsen and Barrow 2015). Музеји на отвореном нуде посетиоцима својеврсни „Пут кроз време”, у којем кроз сопствено искуство уче о прошлости. Искуство не подразумева само знање које су стекли већ и емоције које су осећали током фиктивног боравка у прошлости. И управо се музеји на отвореном фокусирају на искуство које нуде посетиоцима - искуство у прављењу и употреби предмета, искуство живота на који нису навикли (Svendsen 2010, 52). Међутим, искуство које нуде музеји на отвореном - 
предмети који се налазе и производе у њима, куће и реконструкције живота, не треба аутоматски повезивати са експерименталном археологијом (Cunningham et al. 2008, v).

Музеје на отвореном, документарце, емисије, посебне јутјуб канале посвећене старим занатима и технологијама треба уврстити у искуствену археологију. Искуство подразумева да људи сами праве и користе предмете, самостално откривајући својства материјала и технологија (Reynolds 1999a, 161). По једној од дефиниција, искуствена археологија описује покушај људи у садашњости да искусе живот људи у прошлости, кроз акумулацију сопствених искустава, преко разних практичних средстава, као што су - боравак у дивљини, вишедневно искуство живота без склоништа, налет адреналина током лова, ишчекивање јела током касапљења животиње, осећај топлоте поред ватре итд. (Ch'ng 2009, 458). Будући да не постоји једна јасна дефиниција искуствене археологије, најбоље је описати разлику између искуствене и експерименталне археологије. Археолошки експеримент мора одговорити на јасна истраживачка питања. У њему јасно морају бити наведени циљеви и/или хипотезе, као и коришћени материјали и методологија, како би он могао бити поновљен у будућности. У ареолошком експерименту треба навести и варијабле, које треба контролисати у складу са могућностима које пружа дати експеримент (Cunningham et al. 2008, v; Outram 2008). Искуство је важна компонента и у експериментима. Иако су та искуства савремена, експериментални археолози се управо током експеримента боље упознају са материјалима и техникама које користе, на основу чега могу модификовати и неке своје хипотезе и будућа истраживања (Cunningham et al. 2008 , vi). Путем искуства током спровођења експеримента могуће је и осетити одређену дозу емпатије према занатлијама у прошлости, будући да током експеримента архолози могу схватити и колико је велик физички напор био потребан за израду појединих предмета и структура (Reynolds 1999a, 161). Самим тим, сваки експеримент садржи и искуство, док с друге стране свако искуство не представља и експеримент (Cunningham et al. 2008, vi). И искуствена и експериментална археологија имају свој значај у едукацији. Ипак, искуство је најбоље за пренос знања, будући да ће појединац најбоље усвојити знање путем сопственог искуства (Reynolds 1999a, 161). Иако музеје на отвореном треба сврстати у искуствену археологију, они су добра локација и за спровођење археолошких експеримената. Поједини музеји на отвореном сарађују са експерименталним археолозима, те се у склопу њих повремено спроводе и археолошки експерименти, који имају посебан значај у едукацији музејских посетилаца (Comis 2010; Deriu and Ferdella 2010). 
Иако не треба мешати експерименталну и искуствену археологију, обе имају велики значај. Експериментална археологија има циљ да објасни начин израде, употребе и пропадање предмета и структура у прошлости, те има јасан теоријски и методолошки оквир, док искуствена археологија има кључни значај у едукацији шире јавности и промоцији археологије.

\section{Закључак}

Кроз овај приказ експерименталне археологије у свету и код нас, могуће је уочити различите фазе њеног развоја, од појединачних покушаја израде реплика предмета до утемељене поддисциплине археологије, са јасно дефинисаним правилима и теоријско-методолошким оквиром. Из експерименталне археологије развила се и искуствена археологија, која је усмерена ка едукацији шире јавности и промоцији културне баштине, преко емисија занимљивог садржаја и музеја на отвореном. У овим музејима реконструишу се читава насеља и спроводе бројне активности, попут корпарства, ковања метала или израде керамичких предмета, алатки од камена и кости, припреме и конзумације хране, итд. Иако могу бити повезани, потребно је направити разлику између методолошки утемељеног археолошког експеримента и садржаја који нуде пренос искуства. Понекад се ове две гране археологије могу преплитати, а границе између њих постати нејасне. Музеји на отвореном могу бити добра подлога за развој истраживачких центара експерименталне археологије. Овакви истраживачки центри су потребни за спровођење експеримената већих размера, у којима могу учествовати читави тимови стручњака, специјализовани за различите врсте материјала и периода. Потреба за успоствљањем истраживачких центара или званичних институција експерименталне археолгије посебно је изражена у Србији. Без оваквих институција експериментална археологија у Србији ће остати на нивоу експеримената малих размера, који се спроводе искључиво захваљујући ентузијазму појединаца.

\section{БИБЛИОГРАФИЈА}

Ascher, R. 1961. Experimental Archeology. American Anthropologist 63(4): 793-816. Bankoff, H. A. and Winter, F. A. 1979. A house-burning in Serbia: what do burned remains tell an archaeologist?. Archaeology 32: 8-14.

Beck, A. S. 2011. Working in the Borderland of Experimental Archaeology. On Theoretical Perspectives in Recent Experimental Work, in Experimental archaeology: between enlightenment and experience, eds. B. Petersson and L. E. Narmo, 167-194. Lund: Lund University, Department of Archaeology and Ancient History. 
Bogosavljević Petrović, V., Borojević, K., Dimić, V. i Marković, J. 2017. Proces sečenja kultivisanih žitarica u poznom neolitu Srbije - eksperimentalna istraživanja. Arhaika 5: 27-64. Vuković, J. 2011. Neolitska grnčarija - tehnološki i socijalni aspekti. Doktorska teza, Univerzitet u Beogradu.

Vuković, J. 2018. Late Neolithic Vinča pottery firing procedure: Reconstruction of Neolithic technology through experiment. Opvscvla archaeologica 39: 25-35.

Грин, К. 2003. Увод у археологију. Београд: Clio.

Deriu, R. and Fredella, C. 2010. From archeological evidence to experimental reconstruction and back. euroRea 7: 41-45.

Dimić, V. 2019. Hammering the Past: The Experimental (re)construction and usage of Prehistoric Mining Hammerstones from the Prljuša-Mali Šturac site, Rudnik Mountain. Старинар LXIX: 85-112.

Dimić, V. 2020. Izrada i upotreba neolitskog glačanog kamenog oruđa sa sečicom. Eksperimentalna istraživanja i komparativne traseološke analize. Doktorska teza, Univerzitet u Beogradu.

Đuričić, A. 2012. Eksperimentalna arheologija - analiza konstrukcije i gradnja peći na osnovu nalaza sa lokaliteta Vinča - Belo brdo. Master teza, Univerzitet u Beogradu.

Đuričić, A. 2014a. The Construction and Usage of the Neolithic Oven: Experimental Archaeology, in Archaeotechnology: studying technology from prehistory to the Middle Ages, eds. D. Antonović and S. Vitezović, 257-277. Belgrade: Srpsko arheološko društvo.

Đuričić, A. 2014b. Oživljavanje prošlosti: eksperimentalno rekonstruisanje „Boginja sa Blagotina”. Trstenik: Narodni univerzitet Trstenik.

Đuričić, A. 2018. Experimental reconstruction of a Neolithic oven from the site of Vinča, in Algo más que galbos y cacharros. Etnoarqueología y experimentación cerámica/Something more than galbos and pots. Ethnoarchaeology and ceramic experimentation: MENGA Revista de prehistoria de Andalucía, Serie monogràfica 4, eds. E. Alarcón García, J. J. Padilla Fernández, L. Arboledas Martínez and L. Chapon, 329 - 337. Sevilla: Junta de Andalucía Consejería de cultura, Conjunto Arqueológico Dólmenes de Antequera.

Đuričić, A. 2019. Ognjišta i peći u neolitu Centralnog Balkana-tehnike izrade i upotreba. Doktorska teza, Univerzitet u Beogradu.

Evans, J. 1860. On the occurrence of flint implements in undisturbed beds of gravel, sand and clay. Archaeologia 38: 280-307.

Evans, J. 1881. The ancient bronze implements, weapons and ornaments of Great Britain and Ireland. London: Longmans, Green and Co.

Iversen, J. 1956. Forest clearance in the Stone Age. Scientific American 194: 36-41.

Jakobsen, B. and Barrow, S. 2015. Management of Open-Air Museums. OPENARCH.

Kapuran, A. 2007. Eksperimentalna arheološka radionica - Vinča 2001. Petničke sveske 62: 34-38.

Marsh, E. J. and Ferguson, J. R. 2010. Introduction, in Designing experimental research in archaeology: examining technology through production and use, ed. J.R. Ferguson, 1-12. Boulder: University Press of Colorado. 
Mathieu, J. R. 2002. Introduction, in Experimental Archaeology: Replicating Past Objects, Behaviours and Processes, ed. J. R. Mathieu, 1-4. Oxford: BAR International Series, Archaeopress.

Mathieu, J. R. and Meyer, D. A. 1997. Comparing Axe Heads of Stone, Bronze, and Steel: Studies in Experimental Archaeology. Journal of Field Archaeology 24: 333-351.

McGuire, J. D. 1891. The stone hammer and its various uses. American Anthropologist 4: 301-312.

McGuire, J. D. 1892. Materials, apparatus, and processes of the aboriginal lapidary. American Anthropologist 5: 165-76.

McGuire, J. D. 1893. On the evolution of the art of working in stone. American Anthropologist 6: 307-19.

McGuire, J. D. 1894. A study of the primitive methods of drilling. Report of the Unuited States National Museum, Smithsonian Institution 17: 623-756.

Niels, J. 2006. Beowulf's Great Hall. History today 56(10): 40-43.

Nilsson, S. 1868. The Primitive Inhabitants of Scandinavia: An Essay on Comparative Ethnology, and a Contribution to the History of the Development of Mankind: Containing a Description of the Implements, Dwellings, Tombs, and Mode of Living of the Savages in the North of Europe During the Stone Age. London: Longmans, Green and co.

Outram, A. K. 2008. Introduction to experimental archaeology. World Archeology 40 (1): 1-6. Padilla Fernandez, J. J., Giron Anguiozar, L., Đorđević, B. and Đuričić, A. 2014. Rescuing forgotten technologies: the experimental building of a roman pottery kiln in Timacum Minus (Ravna, Serbia). Paper presented at the IV International Congress On Experimental Archaeology, May 8-11, in Burgos, Spain.

Pelegrin, J. 1982. Approche expérimentale de la méthode de production des lamelles d'Orville, in Tailler! Pour quoi faire: Préhistoire et technologie lithique II, eds. D. Cahen and J. Tixier, 149-159. Tervuren: Studia Praehistorica Belgica.

Pelegrin, J. 1984a. Approche technologique expérimentale de la mise en forme des nucléus pour le débitage systématique par pression, in Préhistoire de la Pierre Taillée, 2 Économie du débitage laminaire, eds. J. Tixier, M. L. Inizan et H. Roche, 93-103. Paris: Cercle de Recherches et d'Études préhistoriques.

Pelegrin, J. 1984b. Systèmes expérimentaux d'immobilisation du nucléus pour le débitage par pression, in Préhistoire de la Pierre Taillée, 2 -Économie du débitage laminaire, eds. J. Tixier, M. L. Inizan et H. Roche, 105-116. Paris: Cercle de Recherches et d'Études préhistoriques.

Pelegrin, J. 1984c. Débitage par pression sur silex : nouvelles expérimentations, in Préhistoire de la Pierre Taillée, 2 - Économie du débitage laminaire, eds. J. Tixier, M. L. Inizan et H. Roche, 117-127. Paris: Cercle de Recherches et d'Études préhistoriques.

Pelegrin, J. 1988. Débitage par pression expérimental : « du plus petit au plus grand », Notes et Monographies Techniques du CRA 25: 37-53.

Petersson, B. and Narmo, L. E. eds. 2011. Experimental archaeology: between enlightenment and experience (Vol. 62). Lund: Lund University, Department of Archaeology and Ancient History. 
Radivojević, M. 2014. Cooking met(al): rekonstrukcija najstarije metalurgije na svetu. Rad prezentovan na Međunarodnoj konferenciji Metodologija i Arheometrija, decembar, 4-5, u Zagrebu, Hrvatska.

Rasmussen, M. 2001. Experiments in Archaeology - A View from Lejre, an "Old" Experimental Centre. Zeitschrift für Schweizerische Archäologie und Kunstgeschichte 58: $3-10$.

Rasmussen, M. 2007. Building Houses and Building Theories. Archaeological Experiments And House Reconstruction, in Iron Age Houses in Flames. Testing House Reconstructions at Lejre. Studies in Technology and Culture 3, ed. M. Rasmussen, 6-15. Lejre: Historisk-Arkæologisk Forsøgscenter.

Reynolds, J. P. 1976. Farming in the Iron Age. Cambridge: Cambridge University Press. Reynolds, J. P. 1979. Iron-Age Farm: the Butser experiment. London: British Museum Publications.

Reynolds, J. P. 1980. Butser Ancient Farm: Impressions. Petersfield, Hampshire: Archaeological Research.

Reynolds, J. P. 1985. Iron Age Agriculture Reviewed. Council for British Archaeology Group 12.

Reynolds, J. P. 1994. Experimental archaeology; A perspective for the future. C. J. C. The Reuvens Lecture 5, Stichting voor de Nederlandse Archeologie, Alphen aan den Rijn: 1,3 .

Reynolds, J. P. 1999a. The nature of experiment in archaeology, in Experiment and design; Archaeological studies in Honour of John Coles, ed. A. F. Harding, 156-162. Oxford: Oxbow.

Reynolds, J. P. 1999b. Butser Ancient Farm: A Unique Research \& Educational Establishment, in The Constructed Past: Experimental archaeology, education and the public, eds. P. G. Stone and P. G. Planel, 1-10. London and New York: Routledge.

Saraydar, S. and Shimada, I. 1973. Experimental Archaeology: A New Outlook. American Antiquity 38(3): 344-350.

Semenov, S. A. 1964. Prehistoric Technology, translated by M.W. Thompson. Barnes and Noble: New York.

Siret, L. 1925. Emploi de l'os dans la retouche des silex moustériens. Bulletin de la Société préhistorique de France 22(5): 208-210.

Svensen, A. R. 2010. Learning through experience, euroREA 7: 51-54.

Stevanović, M. 1985. Izgradnja i rušenje kuća u vinčanskoj kulturi eksperimentalno arheološko istraživanje. Magistarska teza, Univerzitet u Beogradu.

Schiffer, M. B. 2013. The Archaeology of Science: Studying the Creation of Useful Knowledge. New York: Springer.

Steensberg, A. 1957. Some recent Danish experiments in Neolithic Agriculture. The Agricultural History Review 5(2): 66-73.

Stone, P. G. and Planel, P. G. 1999. The constructed past: Experimental archaeology, education and the public. London and New York: Routledge. 
Tapavički-Ilić, M. and Mrđić, N. 2015. Roman Burial Rite in Viminacium, The Latest Discovery, in Culti e religiosità nelle province danubiane, Atti del II Convegno Internazionale Ferrara 20-22 Novembre 2013, ed. L. Zebrini, 483-496. Ferara: LAD Laboratorio di studi e ricerche sulle Antiche province Danubiane, Università degli Studi di Ferrara, Dipartimento di Studi Umanistici, Università degli studi di Ferrara.

Texier, P. J. 1984a. Un débitage expérimental de silex par pression pectorale à la béquille. Bulletin de la Societe Prehistorique Francaise 81: 25-27.

Texier, P. J. 1984b. Le débitage par pression et la mécanique de la rupture fragile : initiation et propagation des fractures, in Préhistoire de la Pierre Taillée, 2 -Économie du débitage laminaire, eds. J. Tixier, M. L. Inizan et H. Roche, 139-149. Paris: Cercle de Recherches et d'Études préhistoriques.

Tringham, R. 1978. Experimentation, ethnoarchaeology, and the leapfrogs in archaeological methodology, in Explorations in ethnoarchaeology, ed. R. A. Gould, 169-199. New Mexico: University of New Mexico Press.

Holtorf, C. 2014. The time travellers' tools of the trade: some trends at Lejre. International Journal of Heritage Studies 20(7-8): 782-797.

Carrell, T. L. 1992. Replication and experimental archaeology. Historical archaeology 26(4): 4-13.

Coles, J. M. 1966. Experimental archaeology. Proceedings of the Society of Antiquaries of Scotland 99: 1-20.

Coles, J. M. 1973. Archaeology by experiment. London and New York: Routledge Library Edition.

Coles, J. M. 1979. Experimental archaeology. London, New York: Academic Press.

Comis, L. 2010. Experimental Archaeology: Methodology and new perspectives in Archaeological Open Air Museums. euroREA 7: 9-12.

Cunningham, P., Heeb, J. and Paardekooper, R. eds. 2008. Experiencing archaeology by experiment. Proceedings of the experimental archaeology conference, Exeter 2007. Oxbow Books.

Curwen, E. C. 1930. Prehistoric flint sickles. Antiquity 4: 179-86.

Curwen, E. C. 1935. Agriculture and the flint sickle in Palestine. Antiquity 9: 62-66.

Cushing, F. H. 1894. Primitive copper working; an experimental study. American Anthropologist 7: 93-117.

Ch'ng, E. 2009. Experiential archaeology: Is virtual time travel possible?. Journal of Cultural Heritage 10: 458-470.

Џонсон, М. 2008. Археолошка теорија. Београд: Clio.

Open archeology - open air museums, http://openarchaeology.info/category/archaeologicalopen-air-museum 


\title{
Ana Đuričić \\ Laboratory for Bioarchaeology, Department of Archaeology, \\ Faculty of Philosophy, University of Belgrade \\ Vidan Dimić \\ Archaeological Institute, Belgrade \\ PLACE AND ROLE OF EXPERIMENTAL AND EXPERIENTIAL ARCHAEOLOGY IN THE RECONSTRUCTION OF THE PAST
}

Keywords: experimental archaeology, experiential archaeology, theoretical archaeology, methodology

\begin{abstract}
Experimental archaeology, as a sub-discipline of archaeology, was defined in the second half of the $20^{\text {th }}$ century, but its origins date back to the $19^{\text {th }}$ century. The beginnings of experimental archaeology can only be defined as individual small-scale experiments, without any theoretical base. Those experiments were conducted for the sake of the experiments alone and their results were not compared with other research data. Changes in experimental archaeology follow theoretical and methodological changes in archaeology. Therefore, logical positivism of the processual archaeology was the perfect base for the establishment of experimental archaeology. The hypothetico-deductive method of the new archaeology has remained the main methodological approach in experimental archaeology up until today. In this paper, the formation and changes in experimental archaeology were presented, illustrating different stages that this sub-discipline went through.

The first examples of experimental archaeology in Serbia date back to the late 1970s and the early 1980s, but those experiments were isolated cases. The real emergence of experimental archaeology in Serbia occurred during the first and second decade of the $21^{\text {st }}$ century. Experiments were more frequent in the last decade, and several experimental archaeologists have obtained formal education in this field. Unfortunately, these experiments are still small-scale research activities, conducted without proper funding, fuelled mostly by individual enthusiasm. Examples from the rest of the world have shown that experimental archaeology has to be institutionalised in some way, so that the research could reach its full capacity and so that new generations of experimental archaeologists could be produced. In order for the experimental archaeology in Serbia to grow and develop further, there is a necessity for institutionalisation of experimental archaeology, by opening either an independent research centre or a department within some of the existing institutions.
\end{abstract}


During the second half of the $20^{\text {th }}$ century, large scale and long-lasting experiments started to be conducted, involving not only experimental archaeologists, but specialists from different fields of archaeology. As the number of experimental archaeologists and the complexity of experiments grew, the need for the foundation of formal institutions emerged. Research centres for experimental archaeology were formed in different European countries. In those centres, whole settlements were being reconstructed, including houses, farms, workshops and objects. Opening those centres for the public made a major impact on archaeology and presentation of the past. A new museum type was born - archaeological open-air museum. Those museums consisted of reconstructed settlements from different time periods, showing a variety of activities that people conducted in the past, including, but not limited to: pottery, basketry, textile, stone tool production and metal smelting. In a short period of time, a number of archaeological open-air museums appeared all over Europe, gaining popularity with the public. Seeing the appeal of the mysteries of the past, television houses started making television series which showed different aspects of life, from Prehistory to the Middle Ages and beyond. Now, there is a number of shows and specialised television channels dedicated exclusively to the past - events, intriguing people or everyday activities. The considerable technological progress and the emergence of YouTube gave birth to specialised YouTube channels, which demonstrate various traditional crafts all over the world. However, open air museums, television shows and YouTube channels cannot be considered experimental archaeology, as they lack the theoretical base and obligatory methodological approach. They do offer the experience of the past, so they cannot be classified as experimental, but rather as experiential archaeology. 